Journal of

Accident and

Emergency

Medicine 1994

11, 261-262

\title{
Delayed digital nerve transection as a result of a retained foreign body
}

\author{
D. HUMZAH \& A.L.H.MOSS
}

Department of Plastic Surgery, Queen Mary's University Hospital, Roehampton Lane, London

\section{INTRODUCTION}

Injury to soft tissue structures from a retained foreign body (FB) and subsequent migration is a potential complication. ${ }^{1}$ We report a case of delayed transection of a digital nerve from a retained FB.

Key words: delayed transection, digital nerve, foreign body

\section{CASE REPORT}

A right-handed man aged 28 presented with loss of sensation along the ulnar side of his right little finger (Fig. 1); this had occurred following a blow to this part of the finger. Further questioning revealed that 2 years previously, he had suffered an open injury with glass fragments. This had been debrided

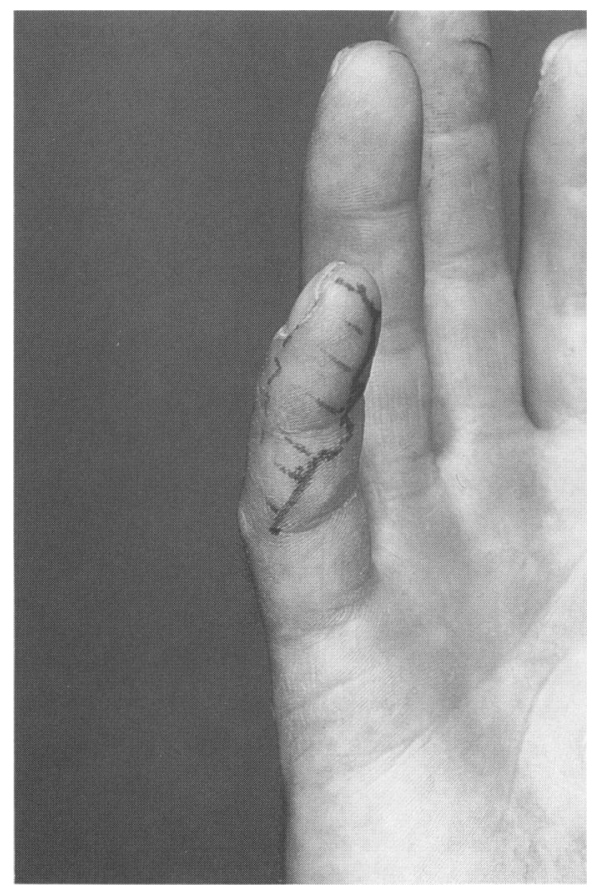

Fig. 1. Loss of sensation on ulnar border of finger. and all but one fragment removed. He had normal sensation following the initial injury.

The radiograph revealed this fragment to be lying on the ulnar border of the finger (Fig. 2). On exploration of this 'closed' injury a fragment of glass was found enclosed in fibrous tissue and transecting the digital nerve (Fig. 3). This area was excised and the nerve repaired. The patient went on to regain sensation along the ulnar border of the finger. The histology of the excised area confirmed nervous tissue surrounded with fibrosis, possibly representing the area where the glass fragment had been embedded.
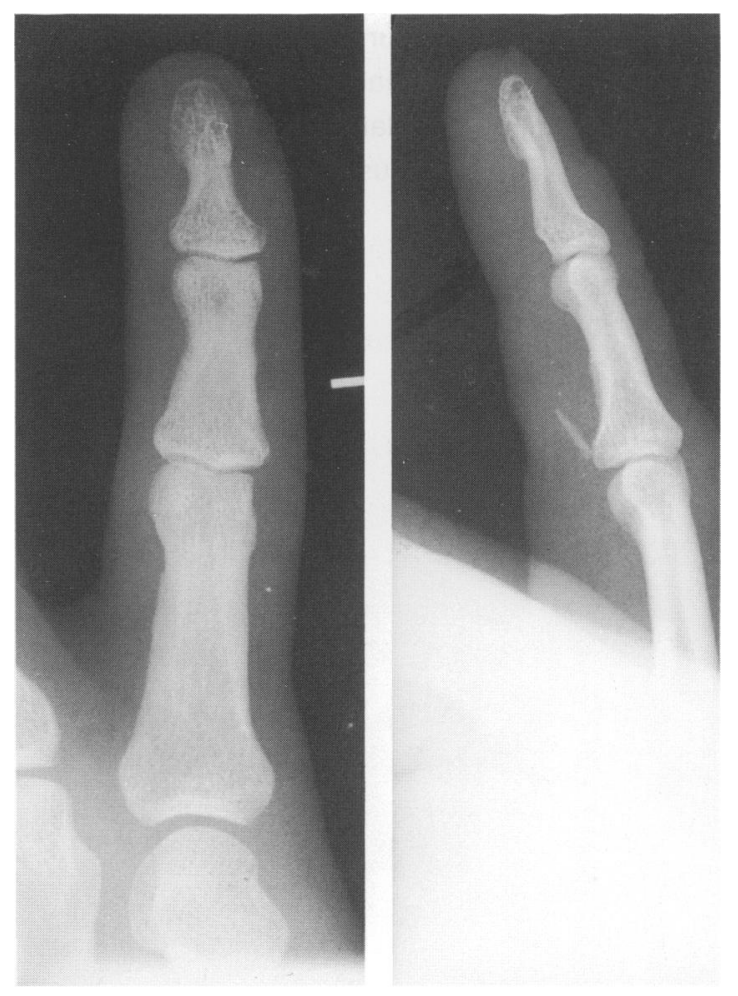

Fig. 2. Radiograph demonstrating location of glass. 
D. Humzah \&

A.L.H. Moss

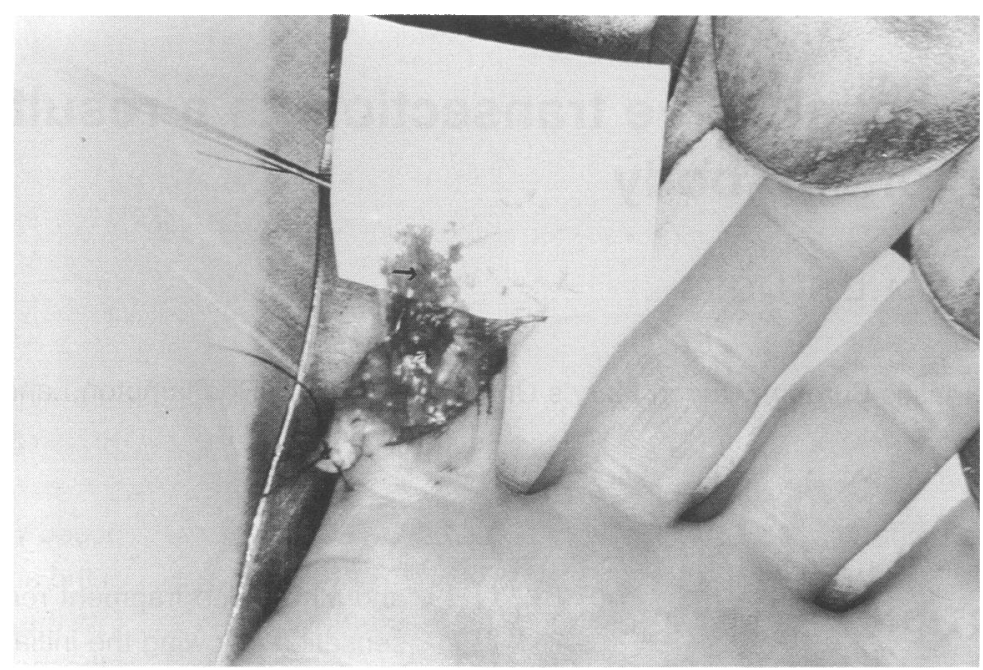

Fig. 3. Intra-operative location of glass transecting nerve.

foreign bodies from mobile areas as they may cause a 'closed injury' as a result of an extrinsic force.

\section{REFERENCES}

1. Chow J. (1988) Foreign body migration in the hand. Journal of Hand Surgery America 13, 462.

2. Lamb D.W. \& Kuczynski K. (1981) The Practice of Hand Surgery, p. 486. Blackwell Scientific Publications, Oxford.

3. Morgan W.J., Leopold T. \& Evans R. (1984) Foreign bodies in the hand. Journal of Hand Surgery (Britain) 9, 194.

4. Anderson M.A., Newmeyer W.L. III \& Kilgore, E.S. Jr. (1982) Diagnosis and treatment of retained foreign bodies in the hand. American Journal of Surgery 144, 63. 